\title{
Sound in Udmurt Rituals
}

\section{Irina Nurieva}

e-mail: nurieva-59@mail.ru

\begin{abstract}
This article is dedicated to the Udmurt's understanding of the world of sounds, their norms of behaviour towards sound in the acoustic community. The Udmurt sound worldview has been formed under the influence of the surrounding landscape. The peculiar sound of the Forest, that the Udmurt see and hear in their particular way, causes a particular sound reaction and musical approach. According to tradition, the voice of a singing person must fit into the natural soundscape in order to respect acoustic balance.

Within the hunting and fishing cults, singing has received the particular function of a magic incantation. The texts of incantatory songs in hunting and in honey producing, are characterised by incantation formulas as well as by different kinds of sound imitations.

The collective community ritual singing is one of the most important elements that organise the Udmurt's soundscape. The acoustic code is integrated in a whole system of ritual practices; it sanctifies the surrounding cultural and natural landscape. The spring-summer half of the year is characterised by a particularly strong intensity of sounds, as in the most significant calendar holiday, the beginning of the agricultural year, Akashka / Byddzh'ym nunal.

The rituals of welcoming have their own aesthetics of sound behaviour. According to the Udmurt community's mentality, the voice of the singing person is not supposed to stand out of the general sound field. Everywhere, the skilful singer occupies a peculiar position on the Udmurt society: they are valued and respected. At the same time, the belief according to which those who are able to sing well are deeply unhappy
\end{abstract}




\section{Irina Nurieva}

in life is very widespread. Taking into account that human voice and singing, in the representations of the Udmurt, possessed a huge force and influence on the surrounding world, we may infer that the singer (the skilful singer!) in the ancient society, who mastered this complicated art, had particular authority. It is even possible that at some moments, he/she fulfilled the function of a mediator between the worlds. And similarly to the shaman, the good singer, usto kyrdzh'as' could not refuse to practice his/her art, this art given him/her by fate.

Thus, the Udmurt's sound worldview is encompassed into an ontological worldview, which sets the rules of behaviour. It requires a proper sound behaviour inside the natural space as well as in the socio-cultural one, and determines the Udmurt's behaviour not only in their natural environment but also in the urban space.

Keywords: ethnic psychology, natural soundscape, sound behaviour, sound ontology, sound and singing's magic, Udmurt

The natural environment is full of different kinds of sounds, noises, voices, which in the traditional awareness are identified and loaded with cultural concepts. In particular, natural sounds may appear as special signs or signals from the world beyond. In the $19^{\text {th }}$ century, the researchers observed that Udmurts immediately reacted to "ordinary phenomena of nature": "An owl shrieks, a dog barks, a pine moans under a strong wind, and the Votyak is already expecting an accident - and how he expects: all the village is alerted, people run from house to house, and share condolences and speculations" (Koshurnikov 1880: 39-40). The numerous beliefs of the Udmurt about natural sounds were reflected in omens:

"if an owl will cry in the yard, in that house there will be a death or some grief";

"if a raven cries on the roof, it announces a fire or another misfortune" (Gavrilov 1891: 148);

"If in spring you hear first on an empty stomach the cry of the cuckoo, - all the year long you will be poor in bread" (Vereshchagin 1995: 115); 
"if the dog howls, lifting his muzzle, there will be a fire, if he just howls it announces a death" (Karpova 2005: 312);

"if during the night you hear the sound of something being thrown in the house, in this house somebody is going to die" (Vereshchagin 2001: 33).

In the traditional culture, there was a whole system of normative behaviour rules, whose aim was to keep in the sound community a balance between the natural and human environments. When, for example, in Spring, one heard the cuckoo for the first time, it was recommended just to roll (Vladykina 1997: 247). In order to transform the grief or the loss in the family foretold by the "howling" of the samovar, one had to hit the samovar a little with one's belt and say: "don't bring grief to us, only to yourself" (Gavrilov 1891: 148). Following a raven who fled over with a shout over our heads towards the North, one should also say: "say good things, bird" (ibid.). The other world could even call a person by his or her name. It was considered as a bad omen to hear one's name in a dream. Therefore, if "somebody unexpectedly hears one's name, as if somebody called her/him, he/she must not answer thrice. Otherwise he will die" (Vereshchagin 2001: 115).

\section{The natural landscape of the Kama region and Udmurt psychology}

The sound ontology of the Udmurt is widely determined by the Forest landscape. The ancestors of the Finno-Ugrians occupied for millennia a huge territory in the Eastern European forest belt. In his famous paleo linguistic research, the Hungarian scholar Péter Hajdú presents some names of taiga trees common to the Ural and Finno-Ugric protolanguages: the fir, the Siberian cedar, the spruce, the larch and the elm (Hajdú 1985: 156). Among the main 


\section{Irina Nurieva}

trees forming whole forests, one must mention the fir - a tree that wields a particular status in the Udmurt religious and mythological picture. Today's taiga fauna comprehends about 50 species of wild animals, among whom many are game. This territory is covered by a dense network of rivers. For centuries, rivers were the main way of communication and the populations concentrated in their shores. For the ancestors of the Udmurt, hunting, fishing, and breeding forest bees were the main subsistence activities. The fur from different species (the marten, the beaver, the ermine, the bear, the fox, the squirrel, etc.), as well as the production of apiculture, were traditionally the main merchandise on which exchange and tax payment relied. 19th century scholars, who visited the Kama region, described brilliantly the local nature: "[...] For dozens of versts, the traveller will see the very same picture [about the road from Vyatka to Glazov - I. N.] - lowlands covered in forests, almost undulating until the horizon. He admires the same view from the hillforts on the right shore of the Cheptsa, nearer to Glazov. If we go deeper south, within this forest area, then turning East and later further south, from every small eminence the traveller will see, again, these very same lowlands, covered by huge, dark portions of forest. [...] The landscape becomes more precise when our traveller enters deeply into these dark woods. The area drops; groves on sand soil alternate with fir woods and coniferous forests that grow directly on the bog.... [...] In the most woody and boggy areas, [...] fifteen years ago in summer all communication between close villages was interrupted. The neighbours waited for winter, in order to be able to visit one another. The culprit were the bogs, so abundant in the forest" (Smirnov 1890: 80-82).

However, even in such harsh conditions, where wild forests and bogs separated rare population pockets, gradually the people was able to conquer from the forest land for cultivation. The archaeologists have found traces of agricultural activities from the Neolithic period. For a long time the rule was the slash-and-burn system. In the natural and climatic conditions of the area, according to Mar- 
garita Grishkina, this archaic system in combination with the use of steam happened to be "extraordinary alive and was practiced in Udmurtia [...] until the late 19 th and even the early $20^{\text {th }}$ century" (Grishkina 2004: 70). The Udmurt were seen as "diligent cultivators": "Agriculture is the main activity among the Votyaks, and we must say that in this field they are the best model of industriousness" (Vladykin 1994: 43). Throughout the centuries, the Kama area was characterised by a complex economy that combined old crafts and a developed agriculture, the first being dominant in the northern areas and the second in the southern ones.

The surrounding nature, undoubtedly, was one of the factors determining the ethnic psychology of the Udmurt. As Lev Gumilev noticed: "[...] the landscape obliges people to elaborate complicated adaptational skills - their ethnic behaviour stereotypes [...] the unique combination of landscapes, in which an ethnic group has grown, determines its behavioural originality - and widely form the point of view of culture" (Gumilev: http://www.kulichki. com/ gumilev/articles). Writer Petr Vail writes an interesting observation: "The connection between a person and the place where he/she lives is mysterious, but obvious. Or in other words: it exists beyond doubt, but it is mysterious. It is managed by the famous and ancient genius loci, the "genius of the place", which connects the intellectual, spirituals and emotional phenomena with their material surroundings" (P. Vail Genius loci: http://lib.ru/PROZA/ WAJLGENIS/genij.txt, accessed 21.05.2021). The link between the natural and geographical environment and the "psychical dispositions" of the Udmurt has been observed since the late $19^{\text {th }}$ century by the scholars and ethnographers. Ivan Smirnov, author of the monograph The Votyaks, highlights: "[...] two features are the undeniable result of the influence of the environing circumstances self-restraint in expressing impressions, which leads to practice silence and the infinite ability to endure - "submission to fate without end". The grim forests are silent, all around the Votyaks, they are silent and the Votyak is silent too, contaminated by his 
surroundings" (Smirnov 1890: 85). Grigoriy Vereshchagin observes the same peculiarity: "The main features in their character - an exceptional shyness, restraint and reticence in expressing their feelings [...] Whether he is joyful or sad, rich or poor, or has some enterprise, you won't know it, he is silent, does not boast either complain about his fate, and if you ask, he answers: "it is to be endured!" (Vereshchagin 1995: 22). This merging with nature, "the permanent emotional contact (dialogue) with nature [...] the disposition towards cooperation with nature, absorption of its 'answers"' (Shklyayev 1998: 20), may be observed until the end of the $20^{\text {th }}$ century.

\section{The soundscape of the forest}

The natural landscape significantly influenced the cultural soundscape. Millennia formed the peculiarities of its profile, sound ideal, of the traditional musical thinking, and this all left its trace on the genetic code of the cultural tradition.

The Udmurt hear and see the Forest in their own way, and its particular sound has caused a corresponding sonic reaction and musical mind-set. According to folk representations, in the forest dwell different spirits, among whom the main one is the Master of the Forest: n'ulesmurt, tshatshtshamurt, bydzh'ym n'un'a, n'ules n'un'a, tshatshtsha n'un'a, s'ikmurt, yagmurt, yagperi, 'Forest man, Great old man, Forest spirit'. The cult of the Master of the Forest today is more widespread among the Northern Udmurt, for in southern Udmurtia the Forest has already been cut down. The Forest man in the mythological awareness is loaded with a powerful force: "He is huge, wears a white cap with a hole on the top, which shows n'ulesmurt's bare pate. He moves inside a whirlwind with tremendous quickness. According the Udmurt beliefs, if a whirlwind hits you, you become paralysed" (Vereshchagin 1996: 89). He brings the wandering persons in deep places and drives them until 
he does not come back to the original place (Vereshchagin 1998: 178). Among the Glazov Udmurts, according to Vereshchagin, he is the god of the forests and the winds, and people bring him regular offerings (Vereshchagin 1998: 214).

The forest, along with land, water and fire, represent the sacred elements, and they have their name day: tel'/tshatshtsha imen'n'ik 'the name day of the forest'. On that day, it is severely prohibited to go into the forest, and even more to cut trees and take off bark. The acoustic code may be the only signal that inform about someone violating the taboo. In one northern Udmurt legend, on the Forest name day, tshatshtsha n'imal'n'ik, a man went to cut wood: "He did not know what day it was, he was already old. Well even if he would have known, he would probably have gone anyway. They called him communist [...] He went to the forest and started cutting trees. Suddenly, somewhere, the sound of an axe was heard [...] this sound comes closer and closer, it is now very near to him, but Bladi does not see anyone [...] Then a whistle started [...] somebody walks noisily and whistles" (Karpova 2005: 233-234). In another legend, also written down in Northern Udmurtia, the situation is analogous (by the river, a woman heard the axe, trees falling, and this ended after she said "oste". It was necessary to give the Forest Master an offering: to put on that place a bit of bread and cereals (Karpova 2005: 515). The informants observe that on that day it also prohibited to sing songs (FWM-2002), clearly in order not to disturb the spirit of the forest.

\section{The magic of singing in the forest rituals}

Within the hunting cults, singing in the forest had a particular role in magic spells. Udmurt traditional culture has retained deeply archaic samples of forest singing: these are hunting and forest beekeeping songs. The first to have collected forest beekeeping songs was Hungarian scholar and linguist Bernát Munkácsi at 
the end of the 19th century in the Malmyzh uyezd (in the villages of Yumgi-Omga and Silo-Pur). For musicologists, it is particularly precious that he made a remark about the text being sung, and not just uttered: "This song, called by the Votyaks mush öt'on gur ("tune for inviting the bees" - I. N.) is sung by the beekeeper, when he prepares a new hive for a future bee swarm; therefore all the words are addressed to the bees" (Munkácsi 1887: 319). Rimma Churakova has recorded a whole collection of forest beekeeping songs (with the tunes!) some years ago in Southern Udmurtia, and she has analysed them in an article (Churakova 2002: 124-174). It was possible yet to record hunting songs in the 1930ies, two of them with the tunes have been published in a collection of articles edited by Evgeniy Gippius and Zinaida Eval'd (Gippius, Eval'd 1989: 15-16, 46-47). The Udmurt folklorists have also managed to record another almost complete sample of hunting singing, s'or kuton gur 'tune for hunting a marten' at the beginning of the $20^{\text {th }}$ century in Central Udmurtia (district of Uva).

The common feature of these songs is faith in the magic strength of the uttered words: the forest beekeeping songs are called to act on the swarming bees, the hunting ones to set a spell on animals. The anonymous author of the essay The Votyaks of the Vyatka Governorate, published in the mid-19 ${ }^{\text {th }}$ century, had the luck to witness a song of hunting spelling during a squirrel hunt, and he writes about it with some irony: "Nowhere the Votyaks song as much as while hunting and especially while hunting the squirrel. They sing to it different panegyrics, in order to have it stop and aim at it better" (Votyaks 1956: 68). The clearly expressed magic function of those songs allowed the scholars to call them "songsspells", "songs-incantation" (Gerd 1997: 130; Churakova 2002: 132).

The texts of the forest songs are in general an improvised description of the process, a developed topic about the future or the present hunt or activities of the bees. 
S’or kuton gur

Oz'y no shuom no

Atased tshuk sultoz

no,

"Kokorik!" kariz ke,

Tel'an potto mon

Dzh'ichied, kioned dory.

Dzh'ichied, kioned

Voz'ma meda ta viyn,

Voz'ma ta kapkanam?

Pumel'ad shed'id ke,

Shumpotis'kod, dyr, uk.

Oy, dzh`ichie, kione,

Shukom val no,

Oz'y shuod uk no.

Mush ut'on gur

Oy, doniosy, doniosy, doniosy, Shunyt shundyya papady.

Doniosy, doniosy, doniosy,

Shunyt shundyya

pozyr"yas'kysa potody, Shunyt shundyya paldyny.

Oy, doniosy, doniosy, doniosy, Dzhuzhyt kyze puks'ody.

Oy, doniosy, doniosy, doniosy, Mi til'edyz oktomy badzh'ym kudyosy,

Oktomy puzho kudyosy.
Hunting song (Selty district)

So, so, we'll say, yes,

Your rooster wakes up in the morning

When "Kokorik!" he sings,

I go out hunting

Hunting the fox, hunting the wolf,

The fox, the wolf,

Are they waiting for me now,

Are they waiting in these traps?

How do you fit in the trap,

We shall so rejoice so,

"Oh, my fox, my wolf"

We say it was, yes

So we tell, it happened.

(Gippius, Eval'd 1989: 47)

Song for forest beekeeping

(Kizner district)

Oh, my dear, dear, dear

Birds of the warm sun,

my dear, dear, dear

with a warm sun, fly in circles

With a warm sun, in order to

swarm.

Oh, my dear, dear, dear

Sit on a high fir

Oh, my dear, dear, dear

We shall gather you in our

great baskets,

We shall gather you by swarms. 
Oy, doniosy, doniosy, doniosy, Oh, my dear, dear, dear, Mi til'edyz korkady

pyrtomy,

Tshoge oshysa voz'omy

dzhytoz'.

Oy, doniosy, doniosy, doniosy, Sobere umortoyady pyrtomy.

Oy, doniosy, doniosy, doniosy, Chil'as' turyn dzhuzhaloz, Chil'as' turyn vyle turly s'as'ka dzhuzhaloz.

Oy, doniosy, doniosy, doniosy, Turly s'as'ka pölys'duno yemysh bich'alody.

We shall bring you back to the house,

We'll hang you on a peg until the evening.

Oh, my dear, dear, dear, Then we will put you in your hive. Oh, my dear, dear, dear, Fresh grass will be lifted, In the fresh grass different flowers will grow. Oh, my dear, dear, dear, Among different flowers precious fruits you will gather. (Churakova 2002: 133-134)

In these forest songs, it is interesting to observe the metaphorical replacement of the address. For example, the bees are called $e$, doniyosy 'eh, my dears', dun papa 'pure bird', biz papaos 'buzzing birds', zarn'i mugor”'yos 'golden bodies'. In songs, as remaks Rimma Churakova, we find another replacement - s'olyktem lul"yos 'sinfree souls', which highlights the high status of this "bird" in the Udmurts' mythological worldview. According to beliefs, along with ordinary bees there are earth bees and heavenly bees. The latter, in mush, have great power: they play after the swarms of ordinary bees have gone out, flying close to the earth. They have their prince, under the rule of which there are countless swarms. When they fly, they overshadow the sun (Vereshchagin 1996: 128).

A characteristic of the magic forest texts is the presence of incantational formulas as refrain dun-dun, dun-dun; doniye-doniye, with different kinds of imitations: the buzzing of the bees, the barking of the dogs, the crowing of the rooster, which, according to Evgeniy Gippius, are "conditional verbal symbols" (Gippius, Eval'd 1989: 16). In different texts, we find a severe imperative: “[...] bees, 
fly here, ringing zhingyr-zhingyr" (Gippius, Eval'd 1989: 16), "Oh, quickly, yes, oh quicky // bees-birds you are. // Through the forest, yes, there, oh yes, through the branches // come here quickly, bees-birds. // Through the forest, yes, there, oh yes, through the branches // come here to me, my bees" (Churakova 2002: 150-151). However, and it is an interesting detail, this imperative of the poetic text (fly, come), which characterises the incantation genres in the folklore tradition, does not find an adequate equivalent in the musical part. In the sample of forest beekeeping tune published by Gippius (recorded in 1937), for example, the tune consists in two melodic phrases, each one of them relied on two related sounds. Indeed, it is not possible to call it a tune in the full sense of the word, it is more a recitativo uttered in a narrow sonic field. The "chamber", "intimate", "conversational" character of the tune is subordinate to the text, which comments the deeds of the beekeeper, who is calling the bees.

Example. Mushöt'on gur. Tune for calling the bees (Uva district)

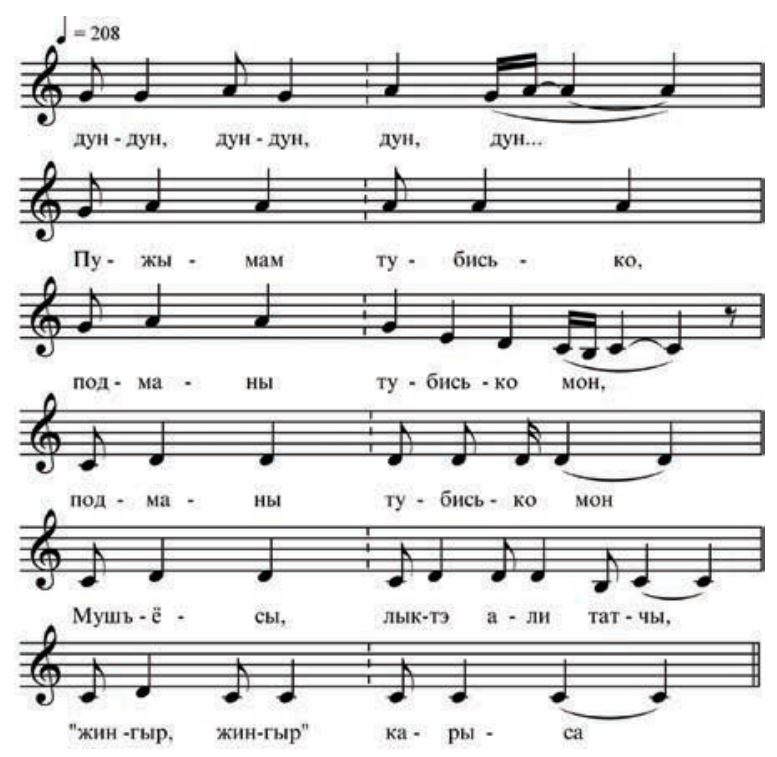


Dun-dun, dun-dun, dun, dun...

I climb on a pine,

I climb on a pine,

I climb on a pine.

Bees, fly here,

Ringing zhingyr, zhingyr.

(Gippius, Eval'd 1989: 15)

Rimma Churakova observes that the forest beekeeping songs in her collection are sung softly, not loud. For example, an informant told her how she remembered her mother, when she climbed a fir to catch a swarm, "quietly sung, explaining her actions and intentions" (Churakova 2002: 133). She also described another very curious performance situation, in which the informant, Aleksandra Serebryakova (Vavozh), who loved her bees and often talked to them, addressed them when they swarmed: "said to them crying: "Where are you flying away? At least you, do not leave me, do not go away!" (Churakova 2002: 138-139). The only description of a performance in another tone is given by Petr Pozdeev: "Matryona Yakovlevna sang in a low voice, straight and strong, so that [...] it was impossible to listen to it quietly, you were taken by shivers" (Churakova 2002: 139).

Echoes of these beliefs are encompassed in folk tales, which describe the effect of these songs on animals: "A Votyak went to gather alms and on the road, he sang a sung. A rabbit heard his song. He liked it a lot. He ran to the man, jumped on the sledge, and started to repeat what he said. Afterwards they met a wolf, who behaved in the same way. Finally, they went further and they met a bear, who also remembered his song, and he also climbed on the sledge and started to sing" (Pervukhin 1889: 27). In this collection by Nikolai Pervukhin, we discover another version of this tale, in which the protagonist is "a woman", who conquered with her voice these same forest animals. Significantly, in the folk tale, the power of the voice on the animals is connected with the crying, 
the chanting. The hero not only sang, "she was skilled in crying and lamenting: "She saw that grief had come to her, and she started to cry and to lament, and a rabbit heard this song of hers, [...] she went on crying and singing more dejectedly then previously, [...] and more desperately she cried, and she lamented even better than before" (Pervukhin 1889: 26).

Contemporary field materials show that the forest remains one of the Udmurt' favourite places for singing. Meanwhile, the singer's voice must blend into the surrounding soundscape: "In the forest I do not sing loud, I do not want with my singing to frighten birds, to disturb the babbling of the brook" (FWM-2013). We must examine in the same line the ban on whistling and of making any loud shout among the Uva (central) Udmurt-Kalmez: "Shaytan"yos pyrozy, perios, nechistoy silaos kylozy no l'ukas'kozy" ('Devils will come, spirits, evil spirits will hear and gather').

In the informants' tales we find the following pattern: they sing in solitude, gathering mushrooms or raspberries, softly, sometimes well-known sad songs, but more often improvising, without words, they sing when grief is in their hearts, therefore often along with the singing, they shed tears: "When I go to the pasture, I walk alone on the meadow. I sing all the day long. I sing and cry. I sing sad songs [...] if I do not know exactly the words, I sing to myself (Udm. as ponnam), I walk anyhow, and sing" (FWM-2000). There is here a clear analogy with the Baltic-Finnic tradition. For example, Valentin Vinogradov describes the phenomenon of lament in the forest in the Veps culture: "Singing in the forest implied the women lamenting their grief. They started with "hurtful" chastushkas, which oriented the singer towards an emotional state. The refrains were performed loudly, and they alternated with a soft, soundless lament" (Vinogradov 2011: 101). The soundless improvised song in the forest with a clear magical purpose (to provide protection from predators for both the singer and her animals) in the Northwest Russia was the object of Mikhail Lobanov's research. Thus, in Novgorod oblast', the women, while they gathered berries, "sang 


\section{Irina Nurieva}

something softly without words. This kind of singing was not formalised at all, the gatherers could start with the tune of whatever long song, or chastushkas or tune with voice accompaniment, then the contours of the song blurred and gave way to a spontaneous improvisation. In general, what to sing - whether something unknown, or repeating part from a song without words - was not regulated. The main thing was how it was performed, as talking to oneself. This kind of singing had a name: it was called, in Russian, nynykat' or tynynykat" (Lobanov 1997: 92). In places with mixed population (Tver Carelians and Russian), the author has also recorded improvisational singing in the Forest. He makes an important observation about forest nicknames: "In performing the nynykan'ya and the improvised tunes, introversion dominates. The singer is fully wrapped up in his/her inner world. By vocalising whatever comes instantly to sound, without repeating any known tune, he/she at that moment is fully independent of the collective factor" (Lobanov1997: 92).

\section{The sound rhythms of the agricultural year}

The collective principle is achieved in ritual community singing, which is an integral part of the everyday life of the traditional agricultural Udmurt society. The "singing element" is ruled by rigorous laws of organisation in time and space. The rhythm of the surrounding nature, of the cosmos itself, acts on the rhythm of the "singing time", sensitively capturing the ups and downs of the year cycle. For ethnomusicologists, the Udmurt understanding of the yearly cyclic times as formed of two independent halves, reflected in acoustic behaviour. The 19th century scholars observed "The civil year is divided, for the Votyaks, into two halves: the first starts approximately in March, the second, in September" (Vereshchagin 1996: 74). The months in each of these halves function in central symmetry: "They (the Udmurt - I. N.) consider Summer and Win- 
ter as two different years [...] The Votyak qualifies Christmas as "green time" as he qualifies February telling that in Summer, at the same time, rye is reap" (Gavrilov 1880: 159). Just as symmetrically are the most dangerous periods, when the borders between the visible and the invisible worlds are particularly fluid: these are the times of the Winter and Summer solstices (Vozhodyr 'sacred time' and Invozho Dyr 'heavenly sacred time'). The winter sacred time of Christmas Vozhodyr allowed to hear sound signals from the other world, which in that period were very sensitive. For example sounds heard at road crossings at midnight announced the future: threshing sounds foresaw good harvest, richness; the sound of woodcutting forebode bad harvest or death, a joyful song from far away, a wedding or good harvest, a sad song, illness and bad harvest (Pervukhin 1888: 127). A bell heard by a girl announced a wedding, by a boy - going to the army. The sounds of an axe or of quarrelling were seen as announcing a death or illness. Sounds heard around barns, granaries or empty houses, foretold either an abundant life (noise of pouring cereals) either starving (sounds of sweeping broomstick) (Popova 2004: 176).

The "sound" behaviour during Summer and Winter solstices was severely regulated. The acoustic code of the sacred time ruled out loud ritual singing, so that it would not disturb invisible spirits, the water, the earth, the nature, while they were gathering new forces. The Northern Udmurt, at winter vozho time, in order not to disturb the inhabitants of the other world, were afraid to walk over a bridge with songs (Pervukhin 1888: 59). In the summer period, invozho, all the actions of the Udmurt farmers were turned towards the protection of the harvest. Any noise made by a person when cereals were blooming could call for a misfortune: "In this period, which lasted circa 10 days or even one month, many activities were banned: digging, cutting wood, building, mowing, knocking, singing, playing instruments [...] The time at the middle of the day was particularly strictly taboo. People were also not allowed to dress in colourful or bright clothes, because the fields risked then to be 


\section{Irina Nurieva}

as colourful" (Vladykin 1994: 188). A lot of prohibitions concerned people's behaviour close to water: it was prohibited to bathe in the river (especially before lunch), to fish, to rinse laundry, to push the herd into the river, to enter the river with sharp objects, to make noise, to whistle and shout, in order not to disturb the spirit of the water. Otherwise, the cereals would be beaten by hail (Gavrilov 1891: 144; Churakova 1995: 83).

\section{The magic of ritual singing}

The community's collective singing of ritual songs is one of the main elements organising the sonic space. The acoustic code is inserted in a whole system of ritual practice, which consecrates the surrounding cultural and natural soundscape. Singing during rituals has never been seen as entertainment. Also in song texts we find emphasised the necessity to perform together special songs in a ritual situation:

Akashka (Gershyd) gur

Mi pyrem ponna vozh"yostes en potte, Mil'emyz buddzh'ymdor kyrdzh'any kossa lez’iz.

Akashka gur

Armis' no lyktem odig pol Akashka nunalmy, Vay kyrdzh'asa-verasa, oy, yyvome.
Tune of the ritual Akashka (Gershyd) (Kizner district)

Do not be angry that we came, The elder of the clan has sent us to sing in each house.

(Churakova 1999: 38)

Tune of the ritual Akashka (Alnashi district)

Once a year comes our day of Akashka,

Let us, oh, rejoince with songs and tales.

(Boykova, Vladykina 1992: 36) 
Akashka (Gershyd) gur Tune of the ritual Akashka

(Gershyd) (Kizner district)

Akashka s'amen kyrdzh'alomy, We sing as in Akashka, Vayele, verale verano kyl"yostes. Tell the words to be put in the song.

(Churakova 1999: 38)

Akashka gur

Mi ke gyne kyrdzh'amy, tuzh cheber kyrdzh'alom, Turly tylobudoyoslen gurenyz. Turly gyne tyloburdolen, oy no, gurenyz, Anayen no ataylen s'amenyz.
Tune of the ritual Akashka (Alnashi district)

If only we sing, we sing very nicely, With the tune of different birds. Only with the tune of a different bird, According to the custom of mother and father. (Boykova, Vladykina 1992: 40)

At the same time, it was prohibited to sing these ritual songs outside the proper ritual time, which also was reflected in the ritual poetics of the Southern Udmurt.

Akashka gur

Kyrdzh'ale, kyrdzh'as' esh"yosy, tunne kyrdzh'an nynalmy,

Tunneles' ke kyl'iz uk, nosh arly kyl'oz uk, Kyrdzh'amdy potoz no, kyrdzh'an dyr uz lu n’i.
Tune of the ritual Akashka (Kizner district)

Sing, my friends - singers, to day is our day for songs,

If today we do not sing, we shall have to wait a whole year, You will want to sing, - but the time for songs will not be.

(Churakova 1999: 37) 


\section{Irina Nurieva}

In the singing calendar of the Besserman, unlike in the Southern Udmurt tradition, there is the feast of Saint Elijah, which divided the summer and autumn seasons. This liminal status of this feast is marked at the auditive code level: "In summer, as soon as the haystacks are set, we may not sing [summer songs - I. N.] anymore. The custom has been set by the elder, and the younger respected it” (Popova 2004: 134).

In some Southern Udmurt local traditions, there is a precise period for learning the ritual songs: "One of the possibilities of transmitting the tradition from generation to generation was the teaching from the elder women to the young girls one week before the given feast and one week after it" (Vladykina 1997: 86). In the Kizner tradition, the learning of the tune Akashka took place one week before the holiday, on Palm Sunday, when it was "allowed to teach the singing of this song, it was necessary to transmit the knowledge and the skill to be able to perform the tunes corresponding to the day" (Churakova 1999: 7).

The spring-summer half of the year is characterised by a higher intensity of sound, and it is opened by the most significant holiday for the Udmurt, the calendar festivity starting the agricultural works, Akashka / Vel'iktem / Badzh'ym nunal. This ritual, as well as the slow spring round dances on the meadow, was an imitation of the wedding ritual in Summer, only near to the winter cultures, and it had a particular timbre, which fulfilled the important mission to have a magical effect on the surrounding micro and macro world. Singing in the open space is reflected in the poetic texts of the Udmurt ritual songs: kyrdzh'am kuaraye kyr"ya koshke... 'my voice pours itself on the horizon as a song'; kyrdzh'ay, dyr, badzh'ym, ay, kuarayen, shukkis'kiz Kumor gurt kuz'a... 'I sang, probably, with a ringing voice (lit: a big voice), the song was heard along the village Kumor' (Nurieva 2004: 68, 101). The (sacred) ringing of the procession in the nuptial songs of the Southern Udmurt may be compared with the metaphor of the mythologic Great Sacred River Töd'y Kam or with the sound of the chipchirgan: 
Yarashon gur

töd'y kamlen tulkymez met

shukkis'koz yardure -

mil'am zhingres kuaramy met kyl'is'kos kyd'oke.

S’uan gur

met shukkis'kos kuaramy kam s'örys'en s'öroz';

takem shuldyr s'uanmy daur"yosyn met kyl'oz.
Song of the processions of the bride's side (Malaya Purga district)

Let the waves of the White River beat the shore, Let our ringing voices let be heard far away. (Kel'makov 1990: 170)

Wedding tune (Malaya Purga district)

Let our voices be heard from one shore of the Sacred river to the other, Let [the remembrance] of such a joyful wedding remain for centuries.

(Kel'makov 1990: 166)

S'uan gur

Shuldyrte ay, shuldyrte, oy, muso no esh"yosy;

Ledzh'e al'i, ledzh'ele chipchirgan golostes.

Chipchirgan golos"yosmes ogadzh'et'i ledzh'om.
Wedding tune (Zav'yalovo district)

Rejoice, yes, rejoice, my dears and my friends.

Sing, sing with the voice of a chipchirgan.

With voices like a chipchirgan let us sing together.

(Kel'makov 1990: 61)

The ethnolinguistic analysis of the Udmurt folk terms, connected with the concept of singing kyrdzh'any, gurlany, shows that they rely on a series of synonymous words around the concept of singing: call, shout, name, sound, sing, loudly cry, make noise, praise 


\section{Irina Nurieva}

(Vladykina 1997: 46-47; Nurieva 1999: 81-82). The definitely loud singing, "unusual" for everyday life, may be assessed not only as a call, an address to the forces of nature, but also an alien speaking, or, according to the saying of Boris Asaf'ev, "an intentional concealment of the timbre of human voice" (in Zemtsovskiy 1976: 898). This "concealment of the voice" is a particular way of behaving, which always become the contrary to everyday life (look for example, at the behaviour of masquerades, of the members of nuptial processions etc.).

The timbre of the ritual songs in the Udmurt tradition is one of the most important musical and stylistic ways of distinguish it, both vertically (ritual and later genres) as well as horizontally (local peculiarities). In the Kukmor singing tradition, for example, the performances of the elder generation have preserved a ritual singing way that reminds an instrumental timbre. Thus, Ariadna Golubkova, the first to draw attention to this feature, highlighted a "nasal" ("oboelike") colouring of the sound (Golubkova, Pozdeev 1987: 9). True, in her arsenal there were only solo recordings of ritual songs. The collective ritual singing, as I see it, is connected with another instrument, the bagpipe. The sound is formed pressuring the vocal cords, which give the impression of a "tight", but sharp sound, through the nose. The local stylistic peculiarities of the Udmurt song melody, with its ongoing development throughout the strophe, the narrow diapason consisting of three sounds, the melismatic repetition of the main tones, are also similar to bagpipes playing. As Igor' Matsievskiy noticed, 'the bagpipes' tunes with the continuity of play, the monotony, the characteristic phrases, based on the alternation of elongated tones and quick transitions typical of the instrument's nature in the framework of a rigidly limited ambitus, have strongly influenced all the European music" (Matsievskiy 2007: 103). Is the similarity of the ritual singing and the timbre of the bagpipes accidental? We know today that the bagpipe was widespread mostly in the Besserman tradition (Steinfeldt 1894: 243-244). However, as the historians suppose, part 
of the Ar Udmurts whose descendants are the Kukmor Udmurts (Napol'skikh 1997: 51-52) may have participated in the ethnogenesis of the Besserman. Moreover, there are traces of presence of the Besserman in this territory also in toponymics. Another mode of performance, noticed by the Eastern Udmurt among the singers of the eldest generation, is the peculiar vibrato on the last sounds of the melostrophe, which evokes the timbre of the kuray.

\section{The aesthetics of sound and the sound behaviour}

The Udmurt traditional society has shaped its particular sound behaviour, and it is expressed in the rituals of welcoming etiquette. The community ritual singing is a symbol of co-unity, co-friendship, compassion. This unity is expressed in a most characteristic detail. When singing around the table, in the welcoming rituals, one of the singers, finishing one strophe, stands up and with two hands he presses the hand of a guest staying in front of him (or of the host, if the guest addressed him). It is indeed difficult to name another field of activity by the Udmurts, where would dominate such atmosphere of mutual understanding and unity:

S'uan s'am

oydo kyrdzh'alom-gurlalom, ay gay,

kel'shoz medam kuyyosmy(y), ay gay?

$\operatorname{Maly}(y)$ uz kel'shy (y)

kuyyosmy (y), ay gay,

Van'myz no $(y)$ as'me

kamanda(y), ay gay.
Nuptial tune

(Kukmor district of Tatarstan)

Come on, let us sing, let us

chant, ay gay,

Shall our tunes fit together,

ay gay?

Why noy merge

with our tunes, ay gay.

If all of us we are

one kin, ay gay.

(Nurieva 1995: 146) 


\section{Irina Nurieva}

According to the mentality of the Udmurt community, when singing a ritual song, the voice of the singer must not stand out of the general sound field. To those who attempt to stand out, in general others comment: Katy en kyrdzh'ale, en kes'as'ke, en cherek"yale ('Do not sing loud, do not shout, do not yell'). This is well shown in the memoirs of a gifted singer from the Eastern Udmurt tradition: "While visiting, the young were even not allowed to sing, but I so wanted to sing. Shertzan (the name of her husband) went out on the porch to smoke, and immediately I started to sing. My husband's mother quietly stood up and went out. As soon as my husband entered from the porch, his mother told me: "Daughter in law, come out from the table, Shertzan is calling you". I already knew that he was going to admonish me, his mother, I suppose has brought him up so. "Why, he said, when you sing, your voice comes out louder than the elders' voice. If you want to sing, sing, but not louder than the elder. When you'll have two or three children, I shall not restrain you". So ignorant they were, they could have said she sings well, she knows how to sing" (Kamaltdinova 2007: 39).

Along with the general understandings about sound aesthetics, in some local groups there are particular, different traditions of values in singing. The Eastern Udmurt, for example, who experienced the strongest influence from the Turkic musical milieu, not only are able to sing the most complicated melodic ornamentation, but have loaned from the Tatars the aesthetic category of $m o^{\circ}$. In Tatar culture, one of the meanings of $m o^{\circ}$ "is not directly translatable in the description of the "performance phenomenon", and covers a whole complex of artistic, emotional and purely musical aspects: mastery, intimacy, ability to create with the performance a particular atmosphere, interpretation freedom, ability to add to the tune rich ornamentation, as well as often including the feeling of sadness, melancholy" (Sayfullina, Sageeva 2009: 81). The concept mynly kyrdzh'as', which exists by the Eastern Udmurt, can be translated as "skilful singer", who has a good musical ear, 
a flexible voice, a good knowledge of lyrics, the ability to transmit through singing an emotional message. The skilful singer pays the role of the leading singer, he or she drags others in his/her wake. If among the singer there are several "skilful singers", they take turns to sing. In the villages, this kind of performer is generally most respected: "Before, they adorned the songs, and they adorn them also today. Just compare, how I sing and how Faniya, she is sings in your style, sound and rhythm, but for us, "a skilful singer" (mynly kyrdzh'as'). Singing with ornaments, not everybody is able to. The "skilful singer" will not be able to do it without efforts. My granny also sang skilfully (mynly), but in her old age she was no more able to sing so well" (Kamaltdinova 2007: 46).

\section{Usto kyrdzh'as' - shudtem lue... (the gifted singer is not a happy person...)}

In the Udmurt traditional culture, there is an ambiguous attitude towards the singing art: on the one hand, the village community deeply appreciates and respects those who know traditional songs, and are able to sing, although the status of the performer-singer in the traditional Udmurt society is significantly different from the status of the performer-instrumentalist. Unlike the latter, even a skilful singer does not stand out in a particular category of persons, and he is not seen as an equal to the master of instrumental play, who received a gift from above. Everybody is expected to be able to sing, and this appears clearly in the ritual situations: to sing out of tune, to stamp out of rhythm, is made fun of and condemned. This kind of singers are called pal'l'an kyrdzh'as' 'a singer at the left'. On the other hand, a very widespread belief says that those who are able to sing well are unhappy in life. There are whole song texts about the unhappy fate of the "skilful singer" the usto / dzh'ech kyrdzh'as': 
Yuon s'am

anay mil'emly no(y) en

kyrdzh'a(y) shuiz,

shuttem no(y) loud no(y) ton (y)

shuiz.

anayles'veramze no pel'am öy

pon,

shuttem nyl"yosyz no(y) mon(y) lui.

Yuon s'am

n'ules(e)ki myni no pu

korany $(y)$,

koram $(y)$ puos no(yy) tyzhy

$\operatorname{tot}(y) \operatorname{mo}(y)$.

pichis'en $(y)$ kyr $(y) z$ 'any no

us(y)to lui,

shuttemmy lueme no(yy)

$\operatorname{tuzh}(y) \operatorname{tot}(y) \operatorname{mo}(y)$.

\section{Guzhem yuon gur}

N'upyr vydem dhz'eg"yosly en s'in'mas'ke esh"yosy, N'upyr vydem dzh'eg"yosyz tis'tem lue, shuo val. Kyrdzhas'-veras' nyl'l'osly en s'in'mas'ke, esh"yosy, Kyrdzhas'-veras' nyl'l'osyz shudtem lue, shuo val.
Welcoming tune

(Kukmor district, Tatarstan)

Mother told us

do not sing,

You will be unhappy,

she said.

I put my mother's words

aside,

Among her children I became unhappy.

(Nurieva 1995: 124)

Welcoming tune

(Kukmor district, Tatarstan)

I walked in the forest to cut

trees

The trees I cut are easy to

recognise.

From childhood I was

a master in singing,

It is well known that I will be unhappy.

(Nurieva 1999: 89)

Tune of the summer feast

(Kizner district)

Do not rejoice at the collapsed

rye, my friends

Collapsed rye may be without grains, they say.

Do not envy singing girls, my friends,

Singing girls happen to be

unhappy, they say.

(Churakova 1999: 68) 
Kuzebay Gerd is the first to have pointed out this characteristic ("the song is connected to the representation of an unhappy person"), and he explained it with the difficulty of being a singer: "to master the singing creativity, means to master a difficult art"; you may achieve perfection only through ordeals in your life (Gerd 2004: 150).

\section{Udmurt zout}

T'il'as'(i) sapegez(y) no(y) aigi kuchchasa no

ektyny(y) usto no mon lui. $\operatorname{turly}(y e)$ nuzh(y)noyez(y) no(y) mon ik adzh'ysa no

kyrd'any (y) usto no mon lui.

Ot'i no tat'i no aigi ve'lysa(y) be'lyny usto mon lui( $(y)$.

anaytem-ataytem ayig

budysa $(y)$

kyrdzh'any usto no mon lui(y).
Udmurt tune

(Mari-Turek district, Mari El)

Wearing bright boots,

I became

a skilful dancer.

Different sufferings,

Seeing, yes

I became a skilful singer.

Walking much here and there, I became a skilful walker.

Having remained without

a mother and a father,

I became a skilful singer.

(Nurieva 1999: 89)

This strange phenomenon is today difficult to explain unequivocally. The singer, the skilful singer, had also particular empowerment. It is not excluded that at some moment he/she had the status of a mediator between the worlds. And that, similar to a shaman, the usto kyrdzh'as' could not give up his art, predetermined by fate.

\section{Conclusion}

Thus, the sound worldview of the Udmurt, which has been forming for millennia, harmoniously integrated in the ontology and consisting in a permanent dialogue within the acoustic community, 


\section{Irina Nurieva}

demanded a strict sound behaviour within the natural world, as well as in the social and cultural space. Until today, this picture determines the behaviour of the Udmurt not only in their traditional milieu, but also in towns and cities.

\section{Sources}

Irina Nurieva's field data 2000 (FWM-2000).

Folklore expeditions of the Udmurt Institute and History, Language and Literature (FE UIIYaL). Record in the village of Baydalino, Yar district from T. Pashkina, born in 1938.

PMA-2002. FE UIIYaL. Enrollment in the village of Yushur, Krasnogorsk district from E. Alekseeva, born in 1928.

PMA-2013. FE UIIYaL. Recording in the village of Chutyr Igra district from T. Korepanova, born in 1964.

\section{References}

Boykova, E., Vladykina, T. 1992. Pesni yuzhnykh udmurtov [Songs of the Southern Udmurts]. I. Izhevsk: Udmurtskiy institut istorii, yazyka i literatury Uralskogo otdeleniya Rossiyskoy akademii nauk.

Churakova, R. 1995. Zvukovoy mir udmurtskogo narodnogo kalendarya [Sound World of the Udmurt Folk Calendar]. In: Golos i ritual [Voice and Ritual]. Moscow: GII.

Churakova, R. 1999. Pesni yuzhnykh udmurtov [Songs of the Southern Udmurts]. Izhevsk: Udmurtskiy institut istorii, yazyka i literatury Uralskogo otdeleniya Rossiyskoy akademii nauk.

Churakova, R. 2002. Bortnich'i pesni v udmurtskoy fol'klornoy traditsii [Forest Beekeeping Songs in the Udmurt Folk Tradition]. In: Etnomuzykovedeniye Povolzh'ya i Urala $v$ areal'nykh issledovaniyakh [Ethnomusicology of the Volga Region and the Urals in Areal Studies]. Izhevsk: Udmurtskiy institut istorii, yazyka i literatury Uralskogo otdeleniya Rossiyskoy akademii nauk.

Gavrilov, B. 1891. Pover'ya, obryady i obychai votyakov Mamadyshskogo uyezda, Urias'-Uchinskogo prikhoda [Beliefs, Rites and Customs of the Votyaks of Mamadysh District, Urias'-Ucha Parish]. II. In: 
Trudy chetvertogo arkheologicheskogo s"yezda v Rossii [Proceedings of the $4^{\text {th }}$ Congress of Archaeologists of Russia]. Kazan: Tipografiya Imperatorskogo universiteta, pp. 80-156.

Gavrilov, B. 1880. Proizvedeniya narodnoy slovesnosti, obryady i pover'ya votyakov Kazanskoy $i$ Vyatskoy guberniy [Productions on Folk Literature, Rituals and Beliefs of the Votyak of Kazan and Vyatka Provinces]. Kazan: Tipografiya A. A. Kokovinoy.

Gerd, K. 2004. Votyak v svoikh pesnyakh [The Votyak in His Songs]. In: K. Gerd Sobraniye sochineniy: $v 6 t$. Stikhotvoreniya, poemy, perevody, stat'i, nauchnyye raboty, pis'ma [Poems, Translations, Articles, Scientific Works, Letters]. Vol. 4. Izhevsk: Udmurtia.

Gerd, K. 1997. Udmurt v svoikh pesnyakh [The Udmurt in His Songs]. In: K. Gerd O ney ya pesn' poyu.... Stikhi i poemy, stat'i i nauchnye raboty, pis'ma [I sing a Song about Her ...: Poems, Articles and Scientific Works, Letters]. Izhevsk: Udmurtia.

Gippius, E., Eval'd Z.1989. K izucheniyu poeticheskogo i muzykal'nogo stilya udmurtskoy narodnoy pesni [To the Study of the Poetic and Musical Style of the Udmurt Folk Song]. Udmurtskiye narodnyye pesni [Udmurt Folk Songs]. Izhevsk: Udmurtskiy institut istorii, yazyka i literatury Uralskogo otdeleniya Rossiyskoy akademii nauk.

Golubkova, A., Pozdeev, P. 1987. Sokrovishche narodnoye: Ocherk ob udmurtskoy narodnoy pesne [Folk Treasure: Essay on the Udmurt Folk song]. Izhevsk: Udmurtia.

Gumilev, L. Ritmy Evrazii [Rhythms of Eurasia]. http://www.kulichki. $\mathrm{com} / \sim$ gumilev/ articles/Article05.htm/.

Hajdú, P. 1985. Ural'skiye yazyki i narody [Ural Languages and Peoples]. K. Maytinskaya (ed.). Moscow: Progress.

Istoriya Udmurtii: Konets XV - nachalo XX veka, 2004 [History of Udmurtia: Late $15^{\text {th }}-$ Early $20^{\text {th }}$ Century]. K. Kulikov (ed.). Izhevsk: Udmurtskiy institut istorii, yazyka i literatury Uralskogo otdeleniya Rossiyskoy akademii nauk.

Kamaltdinova, A. 2007. Dopesennoye i pesennoye intonirovaniye $v$ muzykal'nom fol'klore zakamskikh udmurtov (metodika notirovki zvukozapisey): vyp. kvalifikatsionnaya rabota [Presong and Song Intonation in Musical Folklore of the Eastern Udmurt (Method of Notation of Sound Recordings)]. Izhevsk: Institut iskusstv i dizaina UdGU. Manuscript.

Karpova, L. 2007. Srednechepetskiy dialekt udmurtskogo yazyka: Obraztsy rechi [The Central Cheptsa Dialect of the Udmurt Language: Speech Samples]. Izhevsk: Udmurtskiy institut istorii, yazyka i literatury Uralskogo otdeleniya Rossiyskoy akademii nauk. 
Kel'makov, V. 1990. Obraztsy udmurtskoy rechi 2: sredinnyye govory [Samples of the Udmurt Speech 2: Central Subdialects]. Izhevsk: Udmurtskiy institut istorii, yazyka i literatury Uralskogo otdeleniya Rossiyskoy akademii nauk.

Koshurnikov, V. 1880. Byt votyakov Sarapul'skogo uyezda, Vyatskoy gubernii: Etnograficheskiy ocherk [Life of the Votyak of the Sarapul District, Vyatka Province: Ethnographic Sketch]. Kazan: Tipografiya Imperatorskogo Universiteta.

Lobanov,M. 1997.Lesnyyeklichi:Vokal'nyye melodii-signalyna Severo-Zapade Rossii [Forest Calls: Vocal Melodies-Signals in the North-West of Russia]. Sankt-Petersburg: Izdatel'stvo Sankt-Peterburgskogo universiteta.

Matsievskiy,I.2007. Narodnayainstrumental'naya muzykakakfenomenkul'tury [Folk Instrumental Music as a Cultural Phenomenon]. Almaty: Daik-Press.

Munkácsi, B. 1887. Votják népköltészeti hagyományok [Votyak Folklore Traditions]. Budapest: Magyar Tudományos Akadémia.

Napol'skikh, V. 1997. "Bisermini" ["Bisermins"] in O Besermyanakh [About the Besserman]. G. K. Shklyayev (ed.). Izhevsk: Udmurtskiy institut istorii, yazyka i literatury Uralskogo otdeleniya Rossiyskoy akademii nauk.

Nurieva, I. 1999. Muzyka v obryadovoy kul'ture zavyatskikh udmurtov: Problemy kul'turnogo konteksta i traditsionnogo myshleniya [Music in the Ceremonial Culture of the Trans-Vyatka Udmurt: Problems of Cultural Context and Traditional Way of Thinking]. Izhevsk: Udmurtskiy institut istorii, yazyka i literatury Uralskogo otdeleniya Rossiyskoy akademii nauk.

Nurieva, I. 2004. Pesni zavyatskikh udmurtov [ Songs of the Trans-Vyatka Udmurt] II. Izhevsk: Udmurtskiy institut istorii, yazyka i literatury Uralskogo otdeleniya Rossiyskoy akademii nauk.

Pervukhin, N. 1888 (1). Eskizy predaniy i byta inorodtsev Glazovskogo uyezda [Essays about the Legends and the Everyday Life of NonRussians of the Glazov District]. Eskiz 1: Drevnyaya religiya votyakov po ego sledam $\mathrm{v}$ sovremennykh predaniyakh [Essay 1: The Ancient Religion of the Votyak in Its Traces in Modern Traditions.]. Vyatka: Gubernskaya tipografiya.

Pervukhin, N. 1888 (2). Eskizy predaniy $i$ byta inorodtsev Glazovskogo uyezda [Essays about the Legends and the Everyday Life of Non-Russians of the Glazov District]. Eskiz 2: Idolozhertvennyy ritual drevnikh votyakov po ego sledam v rasskazakh starikov i v sovremennykh obryadakh [Essay 2: The Idol-Sacrificial Ritual of the Ancient Votyak in Its Traces in the Stories of Elder People and in Modern Rituals]. Vyatka: Gubernskaya tipografiya. 
Pervukhin, N. 1889. Eskizy predaniy i byta inorodtsev Glazovskogo uyezda [Essays about the Legends and the Everyday Life of Non-Russians of the Glazov District]. Eskiz 4: Sledy yazycheskoy drevnostiv obraztsakh ustnoy narodnoy poezii votyakov [Essay 4: Traces of Pagan Antiquity in Images of the Oral Folk Poetry of the Votyak]. Vyatka: Gubernskaya tipografiya.

Popova, E. 2009. Kalendarnyye obryady besermyan [Calendar Rituals of the Besserman]. Izhevsk: Udmurtskiy institut istorii, yazyka i literatury Uralskogo otdeleniya Rossiyskoy akademii nauk.

Sayfullina, G., Sageeva, G. 2009. Kategorii tatarskoy traditsionnoy muzykal'noy kul'tury: annotirovannyy slovar' [The Categories of Tatar Traditional Musical Culture: An Annotated Dictionary]. Kazan: Tatarskoye knizhnoye izdatel'stvo.

Smirnov, I. 1890. Votyaki: Istoriko-etnograficheskiy ocherk [The Votyaks. Historical and Ethnographic Essay]. Izvestiya Obshchestva arkheologii, istorii i etnografii pri Imperatorskom Kazanskom universitete. Vol. 8, issue 2. Kazan: Tipografiya Imperatorskogo universiteta.

Shklyayev, G. 1998. Etnicheskaya psikhologiya udmurtov po literaturnym dannym [The Udmurt"s Ethnic Psychology According to Literature]. In: Ob etnicheskoy psikhologii udmurtov [On the Ethnic Psychology of the Udmurts]. Izhevsk: Udmurtskiy institut istorii, yazyka i literatury Uralskogo otdeleniya Rossiyskoy akademii nauk.

Steinfeldt, N. 1894. Besermyane. Opyt etnograficheskogo issledovaniya [The Besserman. Experience of Ethnographic Research]. In: Kalendarya pamyatnaya knizhka Vyatskoy gubernii na $1895 \mathrm{~g}$. [Calendar and memorial book of the Vyatka province for 1895]. Vyatka: Gubernskaya tipografiya, pp. 220-259.

Wail, Petr 2013. Genius of the Place. http://lib.ru/PROZA/WAJLGENIS/genij.txt.

Vereshchagin, G. 1995. Votyaki Sosnovskogo kraya [The Votyak of the Sosnovka Region]. In: Sobraniye sochinyeniy: V6 6 . [Collected Works in 6 Vols]. Vol. 1. Izhevsk: Udmurtskiy institut istorii, yazyka i literatury Uralskogo otdeleniya Rossiyskoy akademii nauk.

Vereshchagin, G. 1998. Kamay. Iz byta votyakov. In: Sobraniye sochinyeniy: Etnograficheskiye ocherki [Collected Essays: Ethnographic essays]. Vol. 3. Izhevsk: Udmurtskiy institut istorii, yazyka i literatury Uralskogo otdeleniya Rossiyskoy akademii nauk.

Vereshchagin, G. 2001. Sobranie sochineniy: V $6 t$. [Collected Works: In 6 Vol.]. Vol. 4: Fol'klor. Book 1: Udmurtskiy fol'klor: Predaniya. Legendy. Pobyval'shchiny. Skazki. Basni. Poslovitsy. Pogovorki. Zagadki [Folklore. Book 1: Udmurt folklore: Traditions. Legends. Stories. Fairy tales. Fables. Proverbs. Riddles]. Izhevsk: Udmurtskiy institut istorii, yazyka i literatury Uralskogo otdeleniya Rossiyskoy akademii nauk. 
Vereshchagin, G. 1996. Votyaki Sarapulskogo uyezda Vyatskoy gubernii. Sobraniye sochinyeniy: $v 6 t$. [The Votyak of the Sarapul District, Vyatka Governorate. Collected Works in 6 Volumes]. II. Izhevsk: Udmurtskiy institut istorii, yazyka i literatury Uralskogo otdeleniya Rossiyskoy akademii nauk.

Vereshchagin, G. 1998. Staryye obychai i verovaniya votyakov Glazovskogo uyezda [Old Customs and Beliefs of the Votyak of the Glazov District]. In: Sobraniye sochinyeniy: $v 6 t$. [Collected Works in 6 Volumes]. Vol. 3. Izhevsk: Udmurtskiy institut istorii, yazyka i literatury Uralskogo otdeleniya Rossiyskoy akademii nauk.

Vinogradov, V. 2011. Golosa lesa v sisteme mifologicheskikh predstavleniy narodov Evropeyskogo Severa [Voices of the Forest in the System of Mythological Representations of the Peoples of the European North]. II. In: Ot kongressa $k$ kongressu: materialy Vtorogo Vserossiyskogo kongressa fol'kloristov [From Congress to Congress: Materials of the Second All-Russian Congress of Folklorists]. Moscow: GRTSRF.

Vladykin, V. 1994. Religiozno-mifologicheskaya kartina mira udmurtov [Udmurts' Religious and Mythological Worldview]. Izhevsk: Udmurtia.

Vladykina, T. 1997. Udmurtskiy fol'klor: problemy zhanrovoy evolyutsii $i$ sistematiki: Monografiya [Udmurt Folklore: Problems of Genre Evolution and Taxonomy. Monography]. Izhevsk: UIIYaL UrO RAN.

Votyaki Vyatskoy gubernii 1856. [The Votyaks of the Vyatka Governorate]. In: Vyatskiye gubernskiye vedomosti [Vyatka News] II, No. 10.

Zemtsovskiy, I. 1976. Narodnaya muzyka [Folk Music]. Vol. III. In: Muzykal'naya entsiklopediya [Musical Encyclopedia]. Moscow: Sovetskaya enciklopediya.

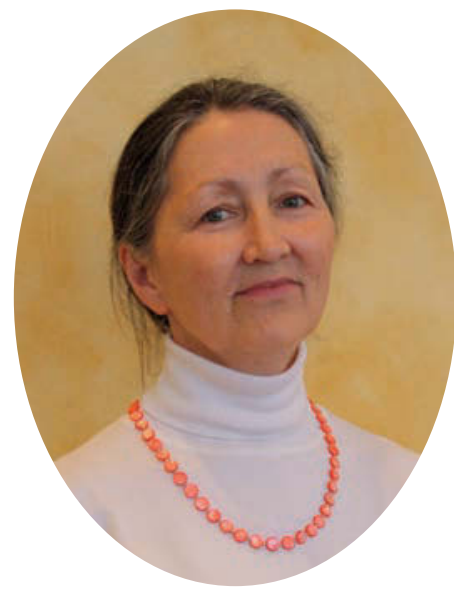

Irina Nurieva, ( $\mathrm{PhD}$ hab) is working as ethnomusicologist at the Udmurt Institute for Research in History, Language and Literature (Udmurt Federal Research Centre of the Ural Branch of the Russian Academy of Sciences). She has worked on Udmurt musical folklore, and has published a series of works about Udmurt folk music.

e-mail: nurieva-59@mail.ru 